\title{
Paradoxical Autonomic Response to Procyclidine in the Neuroleptic Malignant Syndrome
}

\author{
Martin V. Balzan
}

\begin{abstract}
Background: Neuroleptic Malignant Syndrome (NMS) is an adverse reaction to dopamine receptor antagonists, characterised by hyperpyrexia, extrapyramidal rigidity and impaired autonomic function. It might result from central dopamine receptor blockade that causes severe muscle contraction. Method: Case Study. Results: High dose intravenous therapy with the anticholinergic drug, procyclidine hydrochloride, temporarily diminished the muscle rigidity and reversed most of the autonomic features in a patient with NMS occurring after a single intramuscular dose of the dopamine antagonist metoclopramide. Paradoxically, however, the heart rate decreased and bowel movements increased with this atropine-like drug. Conclusion: Since the degree of tachypnoea, tachycardia, and bowel hypotonia closely paralleled the severity of the muscle rigidity, it is suggested that these autonomic features of NMS result from sustained muscle contraction rather than a direct effect of neuroleptic drugs on the central nervous system.
\end{abstract}

\begin{abstract}
RÉSUMÉ: Réponse neurovégétative paradoxale à la procyclidine dans le syndrome malin des neuroleptiques. Introduction: Le syndrome malin des neuroleptiques (SMN) est une réaction indésirable aux antagonistes des récepteurs dopaminergiques caractérisée par une hyperthermie, une rigidité extrapyramidale et une dysfonction neurovégétative. Ce syndrome peut résulter d'un blocage des récepteurs dopaminergiques causant des contractions musculaires graves. Méthodes: Il s'agit d'une étude de cas. Résultats: Le chlorhydrate de procyclidine, un anticholinergique administré à haute dose par voie intraveineuse, a diminué temporairement la rigidité musculaire et a corrigé la plupart des manifestations neurovégétatives chez un patient présentant le SMN à la suite d'une seule injection intramusculaire d'un agoniste de la dopamine. Paradoxalement, le rythme cardiaque a ralenti et le péristaltisme intestinal a augmenté. Conclusions: Comme le degré de tachypnée, de tachycardie et d'hypotonie intestinale étaient en parallèle étroit avec la sévérité de la rigidité musculaire, nous suggérons que ces manifestations neurovégétatives du SMN résultent de la contraction musculaire soutenue plutôt que d'un effet direct des substances neuroleptiques sur le système nerveux central.
\end{abstract}

Can. J. Neurol. Sci. 1995; 22: 244-246

The neuroleptic malignant syndrome (NMS) is a rare serious adverse reaction to central dopamine receptor antagonists, characterised by hyperpyrexia, severe extrapyramidal rigidity and autonomic dysfunction.'

It has been suggested that this syndrome occurs as a result of massive central dopamine receptor blockade with consequent severe muscle contraction. Hyperpyrexia is thought to occur because of increased muscle heat production together with ineffective heat dissipation. However, whether the autonomic features are due to the direct action of neuroleptics on the central nervous system, or if they are the result of the muscle rigidity and body overheating remains unclear. ${ }^{1,2}$

This is a report of a case of NMS caused by a single dose of metoclopramide. Although anti-cholinergic drugs do not appear to be effective in the treatment of this condition, ${ }^{2,3}$ muscle rigidity decreased significantly after the administration of intravenous procyclidine. Furthermore the change in the autonomic features appeared to closely parallel the change in muscle tone.

\section{Case Report}

A 50-year-old man was admitted to a surgical ward for a right inguinal hernia repair. He suffered from hypertension and his blood pressure was well controlled with bendrofluazide $5 \mathrm{mg}$ daily, labetalol $400 \mathrm{mg}$ twice daily and nifedipine $10 \mathrm{mg}$ three times daily. 10 days post-operatively, a local wound infection was drained. Before the procedure, he received $100 \mathrm{mg}$ of pethidine (demerol) and $10 \mathrm{mg}$ of metoclopramide intramuscularly. He was also started on intravenous erythromycin, gentamicin and metronidazole as he was allergic to penicillin. He was noted to be afebrile. Immediately after the procedure the abdomen was soft and bowel sounds were present.

Twenty-four hours later his blood pressure was $80 / 60 \mathrm{~mm}$. His antihypertensive medication was stopped and blood cultures were repeated. Over the next 12 hours he became extremely rigid with a fine tremor. His body temperature was $38.5 \mathrm{C}$ and he was unable to communicate. As he was unable to swallow, intravenous fluids were started. He was incontinent of urine and urinary catheter was inserted. In his abdomen only rare hypokinetic bowel sounds were present.

From the Department of Medicine, Saint Luke's Hospital, Malta.

RECEIVED JANUARY 2, 1995. ACCEPTED IN FINAL FORM MARCH 28, 1995.

Reprint requests to: Dr. Martin V. Balzan. Department of Medicine, Saint Luke's Hospital, Guardamangia, Malta. 
His general condition progressively deteriorated. 48 hours after the procedure he had an irregular respiratory rate of $40-60 /$ minute. His blood pressure was $130 / 80 \mathrm{mmHg}$ and his heart rate was constantly above $140 /$ minute. His white cell count was $22,000 / \mathrm{mm}^{3}$ and creatinine phosphokinase was 428 univ/l (Normal < 100). A CT scan of the brain was unremarkable. Tachypnoeic hypoventilation was present. Arterial $\mathrm{pO}_{2}$ was $85 \mathrm{mmHg}$ on $40 \%$ oxygen. Blood cultures were sterile.

He was transferred to an intensive care unit. Although he was given continuous oxygen, mechanical ventilation was not resorted to. $10 \mathrm{mg}$ of procylidine hydrochloride was given intravenously. Within five minutes his pulse rate was $100 /$ minute, the respiratory rate became $20 /$ minute and regular. His muscle rigidity diminished considerably and the bowel sounds were noted to be brisk and frequent. Although the patient responded to his name by nodding his head he remained mute.

This effect was short lived and within 15 minutes of the administration of procyclidine the heart and respiratory rate returned to their previous levels. Muscle rigidity was again extreme and bowel sounds infrequent and hypokinetic. Procyclidine $10 \mathrm{mg}$ was given three more times at half hourly intervals and the same cycle of events repeated itself.

A nasogastric tube was inserted and he was treated with $220 \mathrm{mg} \mathrm{L}$ dopa every six hours. He improved rapidly and was clinically stable within the next 48 hours. He was then fully conscious and afebrile. Pulse rate was $80 /$ minute, blood pressure $130 / 80$. Muscle rigidity was still present but to a much lesser degree. His muscle tone gradually returned to normal over the next four days.

\section{Discussion}

This patient developed hyperthermia, severe extrapyramidal rigidity and autonomic dysfunction after intramuscular metoclopramide thereby fulfilling Pope's criteria for the diagnosis of NMS. ${ }^{4}$

A number of cases of NMS after a single dose of metoclopramide, occurring in a non-psychiatric patients have been reported in the literature. ${ }^{5-14}$ The interesting observation in this case was the prompt response to the anti-cholinergic drug procyclidine. Furthermore, this anti-muscarinic drug caused a decrease in heart rate and an increase in bowel activity, the opposite of its expected effects when delivered intravenously in high dosage.

NMS is thought to develop with massive central dopaminergic blockade, most commonly with drugs such as chlorpromazine and haloperidol. ${ }^{15}$ As metoclopramide is only a weak central dopamine antagonist it would appear that NMS will arise only in patients with an idiosyncratic central dopamine hypersensitivity to this drug.

Anti-cholinergic drugs such as procyclidine, rapidly reverse acute dystonic reactions resulting from metoclopramide administration. ${ }^{16}$ On the other hand anti-cholinergics do not appear to be of any benefit in cases of NMS. ${ }^{2,3,17}$ In this case intravenous procyclidine caused an immediate reduction in the degree of muscle rigidity. This effect was partial and shortlived. Dowling et al. ${ }^{18}$ have reported a similar rapid reversal of NMS caused by haloperidol with $4 \mathrm{mg}$ of intramuscular benztropine given within 12 hours of onset. It is possible that just as there is an individual susceptibility to neuroleptics, there could also be individual susceptibility for a good response to anticholinergics in NMS.

Even though NMS is characterised by central dopamine depletion, ${ }^{19}$ peripheral hyperadrenergism has been documented. ${ }^{20}$ This increased sypathomimetic activity commonly results in tachycardia and reduced bowel movements.

It is unclear whether tachycardia and bowel hypotonia occur due to a direct effect of the neuroleptic on central autonomic centres or as a consequence of this hyperadrenergic state caused by the severe muscle rigidity and hyperthermia.
As the decrease in heart rate and the increase in bowel sounds paralleled the decrease in muscle rigidity in this case, the second explanation is more likely. This would also explain the paradoxical response of the heart and bowel to anti-cholinergic drugs. Their central effect in decreasing muscle rigidity reduced muscle metabolic demands. Furthermore the decrease in the respiratory rate and increasing lung tidal volume could have improved blood oxygenation. Consequently these two factors probably reduced the intensity of the hyperadrenergic state. This would explain why the direct peripheral autonomic anti-cholinergic effects of the drug were completely outweighed.

Tachypnoea in NMS is thought to be due to decreased chest expansion due to chest wall muscle rigidity. ${ }^{17}$ This would explain why the sudden decrease of the generalised rigidity was accompanied by a decrease in respiratory rate and vice versa.

May et al. ${ }^{21}$ documented a clear parallel between the degree of muscle rigidity as measured by the daily oxygen consumption and the body temperature, respiratory rate, and heart rate. This led the authors to hypothesize that "the basis of the increased thermogenesis and hypermetabolic state was the tonic muscle contraction". Indeed NMS can be compared to a weight lifter at the moment of maximum effort with maximum muscle isometric contraction.

\section{REFERENCES}

1. Caroff SN. The neuroleptic malignant syndrome. J Clin Psychiatry 1980; $41: 79-83$

2. Levenson L. Neuroleptic malignant syndrome. Am J Psychiatry 1985; 142: 1137-1145.

3. Rosebush I, Stewart T, Mazurek MT. The treatment of Neuroleptic Maligant Syndrome. Br J Psychiatry 1991; 159: 709-712.

4. Pope HG, Keck PE Jr, McElroy SL. Frequency and presentation of neuroleptic malignant syndrome in a large psychiatric hospital. Am J Psychiatry 1986; 143: 1227-1233.

5. Robinson MB, Kennett RP, Harding AE, Legg NJ. Neuroleptic malignant syndrome associated with metoclopramide. J Neurol Neurosurg Psychiatr 1985; 48: 1304.

6. Friedman LS, Wienrauch LA, E'elia JA. Metoclopramide induced neuroleptic malignant syndrome. Arch Intern Med 1987; 147: 1495-1497.

7. Samie MR. Neuroleptic-like syndrome induced by metoclopramide. Movement Disorder 1987; 2: 57-60.

8. Cassidy T, Bansal SK. Neuroleptic malignant syndrome associated with metoclopramide. Br. Med J 1988; 296: 214.

9. Patterson JF. Neuroleptic malignant syndrome associated with metoclopramide. South Med J 1988; 81: 674-675.

10. Brower RD, Dreyer CF, Kent TA. Neuroleptic malignant syndrome in a child treated with metoclopramide for chemotherapy related nausea. J Child Neurol 1989; 4: 230-232.

11. Nagashima A, Yao $\mathrm{H}$, Okada $\mathrm{Y}$, et al. A case of metoclopramide induced neuroleptic malignant syndrome with cerebrospinal fluid lactic acidosis. No-To-Shinkei 1991; 43: 387-392.

12. Henderson A, Longdon P. Fulminant metoclopramide-induced neuroleptic malignant syndrome rapidly responsive to intravenous dantrolene. Aust N Z J Med 1991; 21: 742-743.

13. Donnet A, Harle JR, Dumont JC, Alif Cherif A. Neuroleptic malignant syndrome induced by metoclopramide. Biomed Pharmacother 1991; 45: 46I-462.

14. Bakri JN, Khan R, Subhi J, Kawi Z. Neuroleptic malignant syndrome associated with metoclopramide anti-emetic therapy. Gynecol Onc 1992; 44: 189-190.

15. Levinson DF, Simpson GM. Neuroleptic induced extrapyramidal symptoms with fever. Arch Gen Psychiatry 1986; 43: 839-848.

16. Martindale. The extrapharmacopea. In: Reynolds JEF, ed. London: The Pharmaceutical Press, 1993; 892-894.

17. Guze BH, Baxter LR. Neuroleptic malignants syndrome. N Eng! J Med 1985; 313: 163-165. 
18. Dowling JJ, Patrick V. Delirium with dystonia. A variant of the neuroleptic malignant syndrome. Am J Psychiatry 1989; 146: 276-277.

19. Kish SJ, Kleinert R, Minauf $M$, et al. Brain neurotransmitter changes in three patients who had a fatal hyperthermia syndrome. Am J Psychiatry 147; 10: 1358-1363.
20. Feibel JH, Schiffer RB. Sympatho-adrenomedullary hyperactivity in the neuroleptic malignant syndrome. Am J Psychiatry 1981; 138: 1115-1116.

21. May DC, Morris SW, Stewart RM, et al. Neuroleptic malignant syndrome: response to dantrolene sodium. Ann Intern Med 1983; 98: 183-184. 